University of Nebraska - Lincoln

DigitalCommons@University of Nebraska - Lincoln

2009

\title{
Soil Carbon and Nitrogen Accumulation in a Forested Debris Flow Chronosequence, California
}

Judith K. Turk

University of California, Riverside, jturk3@unl.edu

Robert C. Graham

University of California, Riverside, robert.graham@ucr.edu

Follow this and additional works at: https://digitalcommons.unl.edu/conservationsurvey

Part of the Geomorphology Commons, Sedimentology Commons, and the Soil Science Commons

Turk, Judith K. and Graham, Robert C., "Soil Carbon and Nitrogen Accumulation in a Forested Debris Flow Chronosequence, California" (2009). Conservation and Survey Division. 150.

https://digitalcommons.unl.edu/conservationsurvey/150

This Article is brought to you for free and open access by the Natural Resources, School of at DigitalCommons@University of Nebraska - Lincoln. It has been accepted for inclusion in Conservation and Survey Division by an authorized administrator of DigitalCommons@University of Nebraska - Lincoln. 


\section{Soil Carbon and Nitrogen Accumulation in a Forested Debris Flow Chronosequence, California}

\author{
Judith K. Turk* \\ Robert C. Graham \\ Soil and Water Sciences Program \\ Dep. of Environmental Sciences \\ Univ. of California \\ Riverside, CA 92521
}

The role of forest soils in the biogeochemical cycling of $\mathrm{C}$ and $\mathrm{N}$ is most dynamic during the early stages of soil development. To define $\mathrm{C}$ and $\mathrm{N}$ trends that occur with soil development in a mixed coniferous forest, a chronosequence formed by debris flows was studied. The accumulation rates of total organic C (TOC) and total N (TN) were evaluated in soils on 10 debris flow deposits, ranging from $<1$ to $244 \mathrm{yr}$ old. Analysis of the mineral soils was restricted to the 30-cm depth, since this was the depth of the shallowest debris flows. Carbon was found to accumulate in the organic horizons at a rate of $26.5 \mathrm{~g} \mathrm{~m}^{-2} \mathrm{yr}^{-1}$ throughout the time span of the chronosequence. Total organic $\mathrm{C}$ accumulation in the mineral horizons $(0-30 \mathrm{~cm})$ occurred from 0 to $82 \mathrm{yr}$ at a rate of $13 \mathrm{~g} \mathrm{~m}^{-2} \mathrm{yr}^{-1}$, and was nearly stable from 82 to $244 \mathrm{yr}$. Total $\mathrm{N}$ accumulated at a rate of $0.57 \mathrm{~g} \mathrm{~m}^{-2} \mathrm{yr}^{-1}$ in the organic horizons and a rate of $0.17 \mathrm{~g} \mathrm{~m}^{-2} \mathrm{yr}^{-1}$ in the mineral horizons $(0-30 \mathrm{~cm})$ throughout the $244 \mathrm{yr}$ chronosequence. This study suggests that $\mathrm{C}$ accumulation in the upper mineral horizons of young forest soils occurs for $<100 \mathrm{yr}$, while $\mathrm{N}$ accumulation is a slower process that occurs for $>250 \mathrm{yr}$. Carbon and $\mathrm{N}$ accumulation in the organic horizons, however, both follow a linear trend over the 244 -yr period. The rates of $\mathrm{C}$ accumulation suggest a rapid recovery of the soil organic $\mathrm{C}$ pool following disturbance.

Abbreviations: SDEF, San Dimas Experimental Forest; SMRNA, Shasta Mudflow Research Natural Area; TN, total N; TOC, total organic C.
Coil organic matter is a unique soil property in that it reaches $\checkmark$ an approximate steady state in $<5000$ to $20,000 \mathrm{yr}$, which is rapid compared with other soil properties (Birkeland, 1999). In a review of chronosequence studies in a variety of ecosystems, Schlesinger (1990) found a much higher and more variable rate of $C$ accumulation in soils $<3 \mathrm{ka}$ in age $\left(5.7 \pm 1.8 \mathrm{~m}^{-2} \mathrm{yr}^{-1}\right)$ compared with soils ranging from 3 to $10 \mathrm{ka}\left(2.4 \pm 0.7 \mathrm{~m}^{-2} \mathrm{yr}^{-1}\right)$. Thus, when considering the development of soil organic matter pools, it is important to include studies focusing on the early stages of soil development because this is when the most rapid accumulation takes place.

The organic C reservoir in soils is estimated to be $1580 \mathrm{Pg}$, which is greater than the $\mathrm{C}$ pool in land plant biomass and the atmosphere combined (estimated to be $1360 \mathrm{Pg}$ ) (Schimel et al., 1995). In particular, forest soils are considered to be an important sink for organic C. Coniferous forests cover 3.4\% of the Earth's land area (Whittaker and Likens, 1975) and have an average soil organic C content of $15.1 \mathrm{~kg} \mathrm{~m}^{-2}$ (Kern, 1994). Using these values, it can be estimated that there are $75.5 \mathrm{Pg}$ of $\mathrm{C}$ in coniferous forest soils, which is $5 \%$ of the global C pool in soils.

Soil Sci. Soc. Am. J. 73:1504-1509

doi:10.2136/sssaj2008.0106

Received 29 Mar. 2008.

*Corresponding author (judith.turk@email.ucr.edu).

(c) Soil Science Society of America

677 S. Segoe Rd. Madison WI 53711 USA

All rights reserved. No part of this periodical may be reproduced or transmitted in any form or by any means, electronic or mechanical, including photocopying, recording, or any information storage and retrieval system, without permission in writing from the publisher. Permission for printing and for reprinting the material contained herein has been obtained by the publisher.
In the United States, $40 \%$ of forests occur in zones designated as landslide hazard areas (Fig. 1). Thus, the ecosystem recovery and development of soils following disturbance by mass wasting is a natural component of the biogeochemical cycling of forests. In southern California, debris flows are a common type of mass wasting, occurring in several mountainous regions (Morton et al., 2008).

In the current study, debris flow deposits along a particularly active channel were studied as a high-resolution chronosequence, including 10 debris flows ranging in age from $<1$ to $244 \mathrm{yr}$. This approach was useful for focusing on soil formation during the phase in which $\mathrm{C}$ and $\mathrm{N}$ accumulate most rapidly. The study was conducted to resolve trends in TOC and TN which may not be apparent when longer time frames of soil development are considered.

\section{MATERIALS AND METHODS Site Description}

The study site is near the town of Forest Falls in the San Bernardino Mountains of southern California (Fig. 1). The elevation of the site is approximately $1675 \mathrm{~m}$ and an adjacent ridge (Yucaipa Ridge) rises approximately $500 \mathrm{~m}$ above the study area. Yucaipa Ridge is composed mainly of highly fractured gneiss, which produces debris flows during short-duration, high-intensity rainfall events (Morton et al., 2008). The debris flows leave discontinuous levee deposits and lobate deposits with steep-fronted snouts in the forested areas surrounding the debris flow channels. Debris flows on Yucaipa Ridge occur approximately once every $5 \mathrm{yr}$ in three primary debris flow channels (Morton et al., 2008). The channels coalesce at the foot of the ridge to form an approximately 30-ha fan.

The deposits used for this study are on the western bank of one of the debris flow channels, Rattlesnake Creek (N 34. $1^{\circ} \mathrm{W} 116.9^{\circ}$, Datum WGS84). The ages of the deposits range from $<1$ to $244 \mathrm{yr}$ old, as determined using dendrochronological techniques (Turk et al., 2008). The deposits have a north-facing aspect, 9 to $22 \%$ slope gradient, and a convex/ 


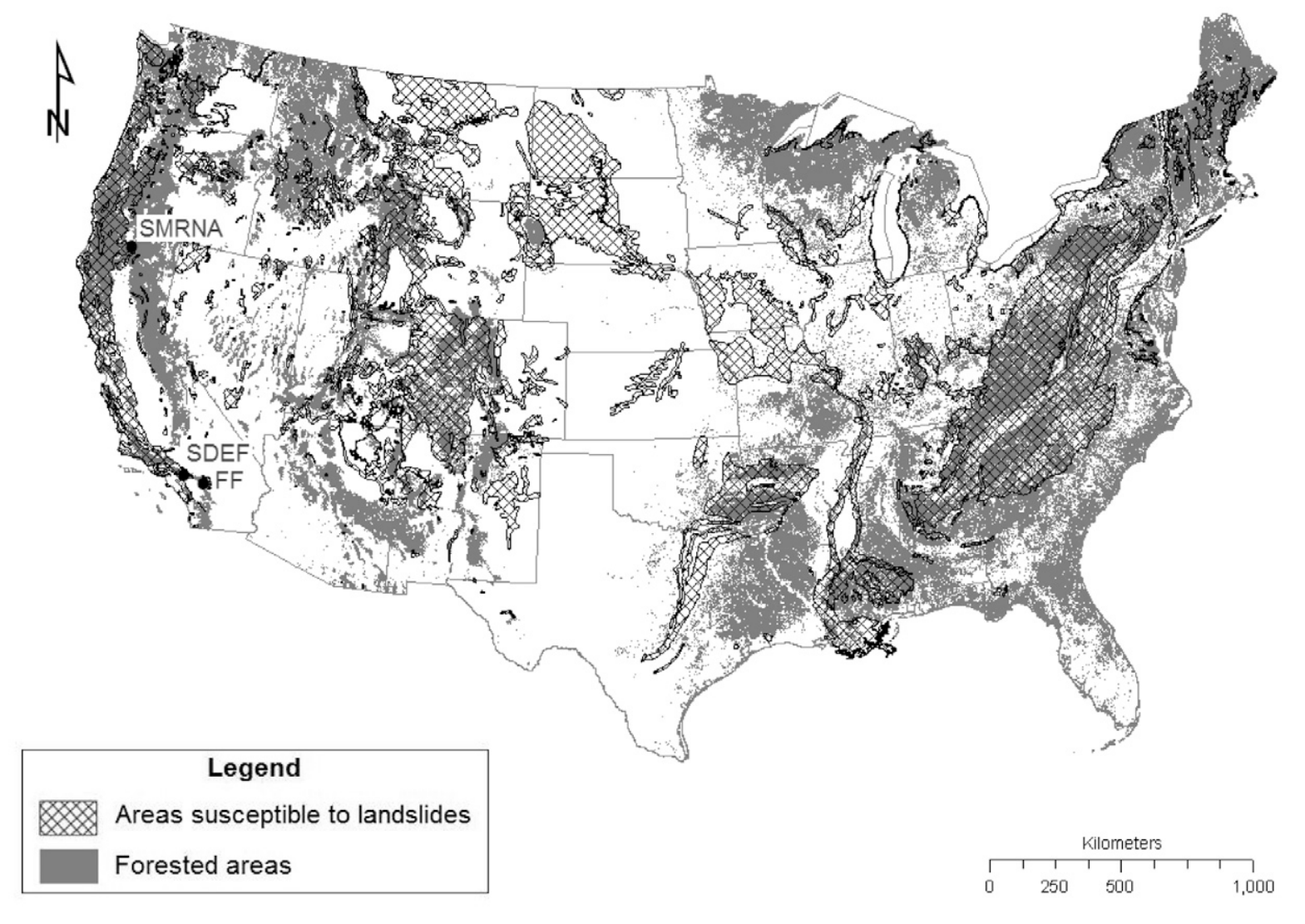

Fig. 1. Map showing the areas susceptible to landslides (Godt, 2001) and forested land (USDA-Forest Service, 2002) in the United States. The location of the study site at Forest Falls (FF) is indicated, as well as the location of the Shasta Mudflow Research Natural Area (SMRNA) (Dickson and Crocker, 1953a, 1953b) and San Dimas Experimental Forest (SDEF) (Quideau et al., 1998, Ulery et al., 1995) studies.

convex slope shape. Individual deposits range from 70 to $900 \mathrm{~m}^{2}$ in area and from 0.3 to $2 \mathrm{~m}$ in thickness. The deposits are composed of loamy coarse sand and unsorted rocks (36-65\% by volume), which range from gravel to stone-size $(2-600 \mathrm{~mm})$. Some woody debris (e.g., branches) is also incorporated into the initial deposits. Very little textural differentiation occurred between the horizons with time in the fine-earth fraction, though there was a decrease in rock fragments of the surface horizons over the course of the chronosequence (Turk et al., 2008). Soils at the site were classified as either sandy-skeletal, mixed, mesic Typic Xerorthents or sandy-skeletal, mixed, mesic Typic Xerofluvents (Turk et al., 2008).

The forest is composed predominantly of incense cedar (Calocedrus decurrens Torr. Florin), with interspersed ponderosa pine (Pinus ponderosa P. Laws. \& C. Laws.), Coulter pine (Pinus coulteri D. Don), California black oak (Quercus kelloggii Newb.), white fir (Abies concolor [Gord. and Glend.] Lindl. ex Hildebr.), and canyon live oak (Quercus chrysolepis Liebm.).

The mean annual precipitation at Forest Falls is $855 \mathrm{~mm}$, with most of the precipitation occurring between November and March, as rain and snow (San Bernardino County Flood Control District, 2008). The mean annual temperature is $12.3^{\circ} \mathrm{C}$, as recorded at a nearby weather station (Camp Angelus, $34.15^{\circ} \mathrm{N} 116.98^{\circ} \mathrm{W}, 1762 \mathrm{~m}$ elevation) (San Bernardino County Flood Control District, 2008).

\section{Soil Sampling}

One soil pit was excavated to the $0.7-\mathrm{m}$ depth on each debris flow. Given the small area of the individual debris flows (70-900 $\left.\mathrm{m}^{2}\right)$, analysis of more than one soil pit per debris flow deposit was not justified, as it would have lead to pseudoreplication and excessive disturbance to the site. The location of the soil pit was chosen in areas that were least influenced by rocky debris flow snouts and erosion processes. The soil pits were described and the $<75-\mathrm{mm}$ fraction of each horizon was sampled for laboratory analysis. Site A was sampled in more than $1 \mathrm{yr}$, using separate pits (Table 1). Each organic horizon was sampled by removing all material from the horizon within the $189-\mathrm{cm}^{2}$ area outlined by a $15.5-\mathrm{cm}$ diameter metal cylinder placed on the soil surface. This was done in triplicate and the three samples were combined. Most organic horizon samples were taken during the summer, so that calculations would be representative of the yearly minimum forest litter. However, the Oi-horizon sample of the 244-yr-old soil was taken in the fall of 2003 , before removal of the 244 -yr-old cohort of trees by logging.

Rock fragments $>75 \mathrm{~mm}$ in length were separated from soil material during excavation of the soil pits and weighed in the field. To determine volume of the soil pits, plastic bags were stuffed with known volumes

Table 1. Summary of debris flow ages. +

\begin{tabular}{|c|c|c|c|}
\hline Site & Surface formation & Sampling & Surface age \\
\hline A & 2003 & 2003 and 2006 & $<1$ and 3 \\
\hline B & 1985 & 2005 & 20 \\
\hline $\mathrm{C}$ & 1977 & 2003 & 26 \\
\hline D & 1954 & 2005 & 51 \\
\hline E & 1930 & 2005 & 75 \\
\hline $\mathrm{F}$ & 1923 & 2005 & 82 \\
\hline G & 1902 & 2003 & 101 \\
\hline $\mathrm{H}$ & 1843 & 2006 & 163 \\
\hline I & 1822 & 2006 & 184 \\
\hline J & 1759 & 2003 & 244 \\
\hline
\end{tabular}

+Turk et al., 2008. 
of Styrofoam peanuts $\left(10-100 \mathrm{dm}^{3}\right)$ and molded into the pit until it was filled. The volume of bags that could fit in the pit was used to approximate the volume of the pit. Extra room was left around the peanuts in the bags so that they could be moved within the bags and the bags could conform to the edges of the pit and the surrounding bags. Small holes were poked in the bags to prevent trapped air from affecting the volume.

\section{Laboratory Methods}

Organic horizon samples were fractionated by hand sorting. The fractions included needles and leaves, woody structures (twigs, bark, and roots), reproductive structures (pine cones, catkins, and acorns), and decomposed unknowns (those components whose botanical origins were not recognizable). Each of the fractions was dried at $65^{\circ} \mathrm{C}$, weighed, and ground with a Wiley mill for $\mathrm{C}$ and $\mathrm{N}$ analysis.

Mineral soil samples were air-dried and sieved to remove gravels $(2-75 \mathrm{~mm})$. The fine-earth $(<2-\mathrm{mm})$ and gravel fractions were weighed. The lab weights and field measurements of rock weight and pit volume (described in the previous section) were combined to determine volume fraction of rock fragment in each horizon (assuming an even distribution of $>75 \mathrm{~mm}$ rock fragments throughout the profile) as follows:

$$
X_{v-c f i}=\frac{W_{c b+}}{V_{p} \times \rho_{p}}+\frac{W_{g r i}}{\frac{W_{f e i} \times \rho_{p}}{\rho_{b i}}+W_{g r i}} \times\left(1-\frac{W_{c b+}}{V_{p} \times \rho_{p}}\right)
$$

Where, $X_{\mathrm{v}-\mathrm{cfi}}$ is the volume fraction of coarse fragments in horizon $i$, $W_{\mathrm{cb}+}$ is the weight of the $>75-\mathrm{mm}$ fragments in the pit (in $\mathrm{kg}$ ), $V_{\mathrm{p}}$ is the volume of the pit $\left(\right.$ in $\left.^{3}\right), \rho_{\mathrm{p}}$ is the particle density $\left(\right.$ in $\left.\mathrm{kg} \mathrm{m}^{-3}\right), W_{\text {gri }}$ is the weight of gravels in the sample from horizon $i$ (in $\mathrm{kg}$ ), $W_{\mathrm{fei}}$ is the weight of the fine earth fraction in the sample from horizon $i$, and $\rho_{\mathrm{bi}}$ is the bulk density of the fine-earth fraction of horizon $i$.

The particle density of the parent material was $2.7 \times 10^{3} \mathrm{~kg} \mathrm{~m}^{-3}$, as measured by the gas pycnometer method (Blake and Hartge, 1986b), using an AccuPyc 1330 pycnometer (Micromeritics, Norcross, GA). Bulk density of the organic horizons was calculated based on the dry weight and core volume of the field samples. Bulk density of the mineral

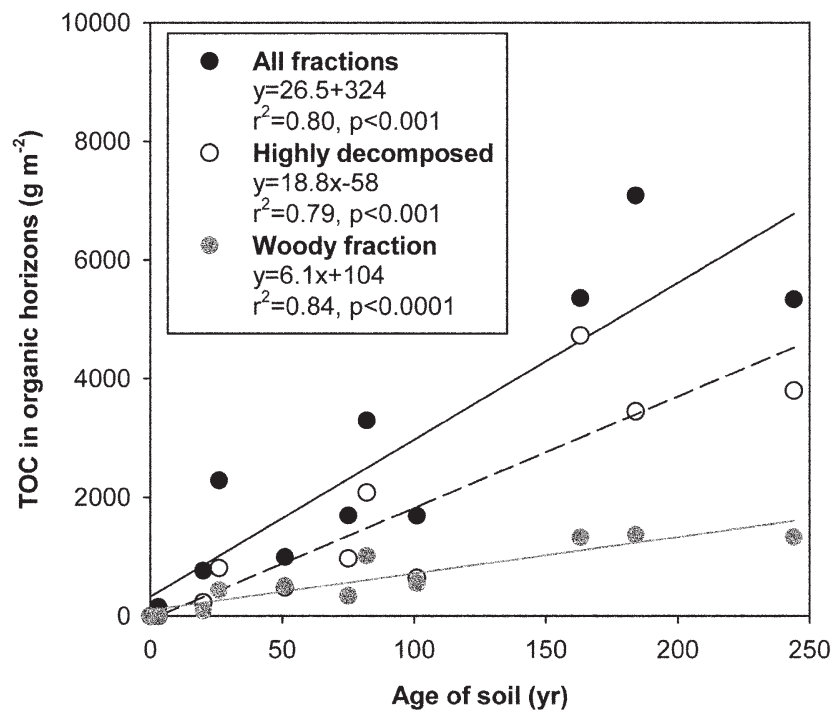

Fig. 2. Total organic carbon (TOC) in the organic horizons (all fractions) and separate components of the organic horizons (highly decomposed and woody fraction). soil horizons was measured using the clod method (Blake and Hartge, 1986a) with corrections for gravel (Hirmas and Furquim, 2006).

The fine-earth fraction was ground to pass through a 100-mesh $(149 \mu \mathrm{m})$ sieve for total $\mathrm{C}$ and $\mathrm{N}$ analysis and carbonate analysis. Total $\mathrm{C}$ and $\mathrm{N}$ were determined by dry combustion using a Thermo-Finnigan Flash EA112 soil combustion N and C analyzer system (CE Elantech, Lakewood, NJ). Carbonate C, which was present in the $<1$ - and 3-yrold soils, was measured by the manometer method (Williams, 1948), using a Dwyer series 477 digital-manometer (Dwyer Instruments, Inc., Michigan City, IN). Total organic C (TOC) was determined by subtracting carbonate $\mathrm{C}$ from total $\mathrm{C}$.

Concentrations were converted to mass per area $\left(\right.$ in $\mathrm{g} \mathrm{m}^{-2}$ ) as follows:

$$
\frac{M}{A}=\sum_{i=1}^{n}\left[T_{i} \times \rho_{b} \times C_{i} \times\left(1-X_{v-c f i}\right)\right]
$$

(Boone et al., 1999). Where $M$ is mass (in g), $A$ is area (in $\mathrm{m}^{2}$ ), $n$ is the number of horizons in the soil, $T_{\mathrm{i}}$ is the thickness of horizon $i$ (in $\mathrm{m}$ ), $P_{\mathrm{bi}}$ is the bulk density of horizon $i$ (in $\mathrm{kg} \mathrm{m}^{-3}$ ), $C_{i}$ is the concentration of $\mathrm{C}$ or $\mathrm{N}$ in horizon $i$ (in $\mathrm{g} \mathrm{kg}^{-1}$ ), and $X_{\mathrm{v}-\mathrm{cfi}}$ is the volume fraction of coarse fragments in horizon $i$. Mass of TOC and TN per area were calculated for the organic horizons and for the upper $30 \mathrm{~cm}$ of the mineral soil. The depth of $30 \mathrm{~cm}$ was chosen because this was the shallowest depth at which buried A horizons were encountered. We wanted to assess TOC and TN accumulation in fresh parent material, so buried horizons needed to be excluded.

\section{RESULTS AND DISCUSSION Organic Carbon Accumulation}

Most of the $\mathrm{C}$ accumulation in the soils formed at the Forest Falls debris flows occurred in the organic horizons. The rate of $\mathrm{C}$ accumulation in the organic horizons was determined to be $26.5 \mathrm{~g} \mathrm{~m}^{-2} \mathrm{yr}^{-1}$ (Fig. 2). Accumulation of $\mathrm{C}$ in the organic horizons occurred predominantly in two fractions: the decomposed fraction (decomposed beyond recognition of botanical origins) and the woody materials (twigs, bark, and roots). The rates of $\mathrm{C}$ accumulation in these fractions $\left(18.8 \mathrm{~g} \mathrm{~m}^{-2} \mathrm{yr}\right.$ for decomposed fraction and $6.1 \mathrm{~g} \mathrm{~m}^{-2} \mathrm{yr}$ for woody materials) nearly account for the total $\mathrm{C}$ accumulation rate in the organic horizons. Other organic horizon fractions (needles and leaves and reproductive structures) were variable in their contribution to the $\mathrm{C}$ pool, but did not display a significant trend in with time. Carbon originating from needles and leaves was apparently accumulated in the decomposed fractions, reflecting the rapid decomposition of these structures (Swift et al., 1979).

Organic $\mathrm{C}$ accumulation in the mineral soil is slower and shorter-lived than in the organic horizons. In the mineral soil, organic $\mathrm{C}$ accumulation occurs from $<1$ to $82 \mathrm{yr}$ and the rate of accumulation during this stage is $13 \mathrm{~g} \mathrm{~m}^{-2} \mathrm{yr}^{-1}$ (Fig. 3). From 82 to $244 \mathrm{yr}$ the $\mathrm{C}$ pool in the mineral soil is nearly stable, there is a slight decline in the size of the TOC pool, but the trend is not significant (Fig. 3). These trends are similar to those observed in the chronosequence at Shasta Mudflow Research Natural Area (SMRNA), located in the Cascade Range of northern California. Both sites show the most rapid C accumulation in soils $<100 \mathrm{yr}$ old (Dickson and Crocker, 1953b).

To interpret the $\mathrm{C}$ accumulation rates calculated from this chronosequence in a broader context, it is important to recog- 
nize the limitations and assumptions of the calculated chronofunctions. In most of the debris flows (Sites A, B, D, F, G, and I) buried A horizons were observed within $100 \mathrm{~cm}$ of the soil surface. Although not observed, the other sites are assumed to have buried A horizons within $2 \mathrm{~m}$ of the surface, based on the maximum thickness of individual deposits observed in crosssections exposed in the debris flow channels. To calculate the amount of $\mathrm{C}$ accumulated since the most recent debris flow, it was necessary to exclude the $\mathrm{C}$ in the buried soil, which predates the debris flows at the surface. Therefore, the $\mathrm{C}$ pool reported here only includes the depth to the shallowest buried A horizons, which were at $30 \mathrm{~cm}$. This calculation leaves out a significant portion of the $\mathrm{C}$ pool that accumulates deeper in the soils, through 100-cm depth, due to root growth (Turk et al., 2008). At sites where a buried A horizon was not encountered within $100 \mathrm{~cm}$ of the mineral soil surface (Sites $E$ and $J$ ) the upper $30 \mathrm{~cm}$ of the soil accounted for only $50 \%$ of the TOC stored in the mineral soil. Thus, it cannot reasonably be assumed that most $\mathrm{C}$ from root deposition and decay accumulates in the upper $30 \mathrm{~cm}$, but by necessity, the chronofunctions presented here exclude this deeper $\mathrm{C}$.

The shallow buried A horizons and the small area of the debris flows (70-900 $\mathrm{m}^{2}$ ) probably themselves affect ecosystem development, further limiting the applicability of the chronofunctions to soil development on larger geologic deposits. Since the developing forest grows both in the fresh debris flow deposit and in what may be a well-developed A horizon as little as $30 \mathrm{~cm}$ beneath the surface, the debris flows are somewhat intermediate between a primary and secondary successional chronsequence. There are also two important effects of the small area of the individual debris flows (i) colonization from surrounding vegetated areas is almost immediate and (ii) much of the litter deposited on a fresh debris flow surface originates from vegetation on older debris flows adjacent to the young surface. These effects were illustrated on the 3-yr-old debris flow deposit, which had a dense cover of incense cedar seedlings $\left(150 \mathrm{~m}^{-2}\right)$ (Turk et al., 2008) and a nearly continuous, 1 -cm-thick layer of litter from mature trees on the surrounding debris flows.

In spite of these limitations, some comparisons can be made with other studies of the early stages of soil formation under coniferous vegetation in California. Related studies include the lysimeter biosequence at the San Dimas Experimental Forest (SDEF) in the San Gabriel Mountains in southern California (Ulery et al., 1995) and the chronosequence at SMRNA (Dickson and Crocker, 1953a) (Fig. 1). Comparison between Forest Falls, SMRNA, and SDEF reveals differences in the profile distributions and rates of $\mathrm{C}$ accumulation (Table 2). Forest Falls has a distinctly different profile distribution of $\mathrm{C}$ compared with the other sites. At Forest Falls, $\mathrm{C}$ accumulates rapidly in the organic horizons and at a lower rate in the mineral soil, however, the inverse is true at SMRNA and SDEF. This trend may be caused by trees growing on older debris flows which contribute leaf litter to the younger debris flows, but do not contribute root biomass. Another factor may be the influence of poor air quality in the San Bernardino Mountains on the tree growth at Forest Falls. Ozonesensitive conifers exposed to high levels of ozone and atmospheric $\mathrm{N}$ deposition have high shoot/root ratio and high rates of foliar turnover, leading to a thick forest floor (Takemoto et al., 2001).

Comparing the sum of $\mathrm{C}$ accumulation rate in the organic and mineral horizons (Table 2), the data show lower rates of ac- cumulation at the warmer, drier sites (Forest Falls and SDEF) compared to the cooler, wetter SMRNA chronosequence. These data support the general observation of greater soil C pools as temperature decreases and precipitation increases (Post et al., 1982). Overall, the rates of $C$ accumulation at all three young, forested sites (39.3-139.8 $\mathrm{g} \mathrm{m}^{-2} \mathrm{yr}^{-1}$ ) (Table 2) are high in comparison with those observed in chronosequence studies involving older landscapes and other ecosystems in California. Rates of 0.26 to $5.4 \mathrm{~g} \mathrm{~m}^{-2} \mathrm{yr}^{-1}$ for soil organic $\mathrm{C}$ through the 30 -cm depth can be calculated from the earliest stages of soil development considered in chronosequence studies of grasslands and coastal scrub (Harden, 1987, Harden et al., 1987). This difference in C accumulation rates can be attributed partly to differences in the $\mathrm{C}$ balance of these ecosystems. Generally higher $\mathrm{C}$ storage is observed in forest soils compared with grasslands and scrublands (Kern, 1994). However, it is also important to consider the time span of the chronosequence. In the grassland and coastal shrub chronosequences the difference in age between the youngest two surfaces is $>1000 \mathrm{yr}$ (Harden, 1987, Harden et al., 1987). These early years of soil development may include trend reversals and changes in the $\mathrm{C}$ accumulation trend, as observed in the mineral soil horizons at Forest Falls and Mt. Shasta (Dickson and Crocker, 1953b) and an overall trend toward a slower accumulation rate with time, as described by Schlesinger (1990).

Given a longer time span at Forest Falls, it is expected that the linear trend in $\mathrm{C}$ accumulation of the organic horizons would approach an approximate steady state level. The oldest site observed in the study (244 yr old) stored about $9 \mathrm{~kg} \mathrm{~m}^{-2}$ of $\mathrm{C}$ through the 1-m depth (starting from the surface of the organic horizons), which is lower than the average $\mathrm{C}$ content for soils in temperate coniferous forest $\left(15.1 \mathrm{~kg} \mathrm{~m}^{-2}\right)$ (Kern, 1994). A prediction of when steady state will be reached can be made by extrapolating the trends from this chronosequence $\left(26.5 \mathrm{~g} \mathrm{~m}^{-2}\right.$ accumulation in the organic horizons and no further accumulation in the mineral soil) and assuming that the steady state level of $\mathrm{C}$ is around $15.1 \mathrm{~kg} \mathrm{~m}^{-2}$. If the assumptions of this prediction hold, it is estimated that the $\mathrm{C}$ pool stabilizes $230 \mathrm{yr}$ beyond the last age represented in the chronosequence, or within about $500 \mathrm{yr}$ of

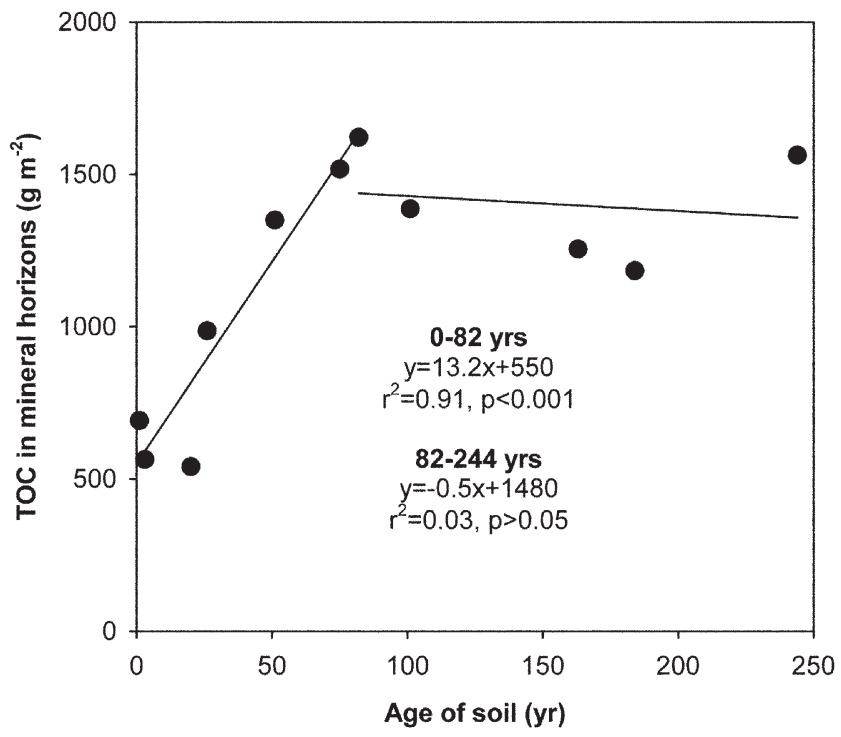

Fig. 3. Total organic carbon (TOC) in the mineral soil horizons through a depth of $30 \mathrm{~cm}$. 
Table 2. Climate conditions, vegetation, and rates of carbon and nitrogen accumulation calculated for short-term $(<300 \mathrm{yr})$ soil formation over under coniferous vegetation in California.

\begin{tabular}{|c|c|c|c|}
\hline & $\begin{array}{c}\text { San Dimas } \\
\text { Experimental } \\
\text { Forest }\end{array}$ & Forest Falls & $\begin{array}{c}\text { Shasta Mudflow } \\
\text { Research Natural Area }\end{array}$ \\
\hline \multicolumn{4}{|c|}{ Climate } \\
\hline Mean annual precipitation, $\mathrm{cm}$ & 678 & 855 & 1300 \\
\hline Mean annual temperature, ${ }^{\circ} \mathrm{C}$ & 14.4 & 12.3 & 10 \\
\hline Vegetation & $\begin{array}{l}\text { Coulter pine } \\
\text { monoculture } \\
\text { Organic Ca }\end{array}$ & $\begin{array}{l}\text { Mixed coniferous forest } \\
\text { rbon, } \mathrm{g} \mathrm{m}^{-2} \mathrm{yr}\end{array}$ & Mixed coniferous forest \\
\hline Organic Horizons & $10.7^{\dagger}$ & 26.5 & 52.8 \\
\hline Mineral Soil (upper 30 cm) & $29^{\ddagger}$ & $13^{\S}$ & $87^{\#}$ \\
\hline Total & 39.7 & 39.5 & 139.8 \\
\hline \multicolumn{4}{|c|}{ Total Nitrogen, $\mathrm{g} \mathrm{m}^{-2} \mathrm{yr}$} \\
\hline Organic Horizons & $0.3 \overline{4^{\dagger}}$ & 0.63 & 1.13 ฯ \\
\hline Mineral Soil (upper 30 cm) & $1.56^{\ddagger}$ & 0.17 & $1.20^{\top}$ \\
\hline Total & 1.90 & 0.80 & 2.33 \\
\hline
\end{tabular}

† Quideau et al., 1998 (Coulter pine site).

\# Ulery et al., 1995 (Coulter pine site).

§During accumulation phase $(<1-82 \mathrm{yr})$.

ฯ Dickson and Crocker, 1953b, 1954 (27-255 yr-old mudflows).

\#Dickson and Crocker, 1953b, 1954 (during accumulation phase, 27-60 yr-old mudflows).

organic horizon: the decomposed fraction and the woody materials. Nitrogen accumulated in the decomposed fraction at a rate of $0.49 \mathrm{~g} \mathrm{~m}^{-2} \mathrm{yr}^{-1}$ and in the woody materials at a rate of $0.08 \mathrm{~g} \mathrm{~m}^{-2} \mathrm{yr}^{-1}$, thus accounting for most of the $\mathrm{N}$ accumulation rate in the organic horizons. The rate of $\mathrm{N}$ accumulation in the mineral horizons was $0.17 \mathrm{~g} \mathrm{~m}^{-2} \mathrm{yr}$, but exhibits a high level of variability (Fig. 5). The upper $30 \mathrm{~cm}$ accounts for $52 \%$ of the $\mathrm{N}$ storage through the $100-\mathrm{cm}$ depth in the 244-yr-old debris flow, revealing that the upper $30 \mathrm{~cm}$ provides an underestimate of total $\mathrm{N}$ stored in the mineral horizons of the soils.

The total rate of $\mathrm{N}$ accumulation in the Forest Falls chronosequence $\left(0.80 \mathrm{~g} \mathrm{~m}^{-2} \mathrm{yr}^{-1}\right)$ is lower than the rates of $\mathrm{N}$ accumulation determined for both the SMRNA $\left(2.33 \mathrm{~g} \mathrm{~m}^{-2} \mathrm{yr}^{-1}\right)$ and the $\operatorname{SDEF}\left(1.9 \mathrm{~g} \mathrm{~m}^{-2} \mathrm{yr}^{-1}\right)$ (all

soil development. This rapid achievement of steady state was also observed in the SMRNA chronosequence, in which the soil C pool was observed to be nearly stabile after $600 \mathrm{yr}$ (Dickson and Crocker, 1953b, Lilienfein et al., 2003). This represents a much more rapid stabilization of the soil $\mathrm{C}$ pool than the general observation that soils reach steady-state organic C levels in $<5000$ to 20,000 yr (Birkeland, 1999). These results indicate that the $\mathrm{C}$ pool of soils of the mixed coniferous forests in California recover rapidly from disturbance by mass wasting.

\section{Nitrogen Accumulation}

Nitrogen accumulation in the organic horizons occurred at a rate of $0.63 \mathrm{~g} \mathrm{~m}^{-2} \mathrm{yr}^{-1}$ (Fig. 4). As observed for $\mathrm{C}$ storage, the $\mathrm{N}$ accumulation occurred primarily in two fractions of the

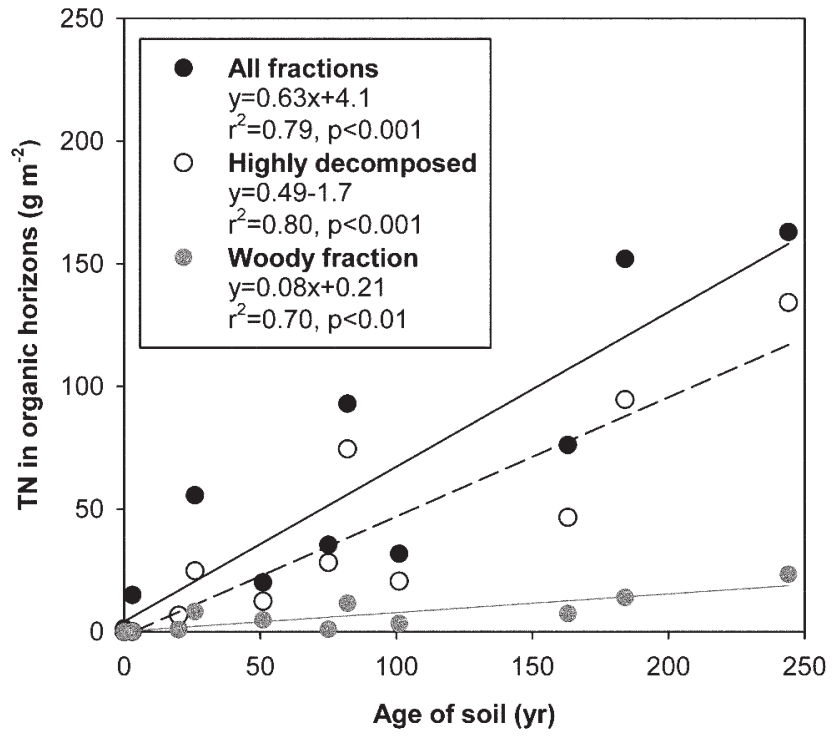

Fig. 4.Total nitrogen (TN) in the organic horizons (all fractions) and separate components of the organic horizons (highly decomposed and woody fraction). calculated through 30-cm depth) (Table 2). The higher $\mathrm{N}$ accumulation rate at SMRNA could be related to the abundance of plant species that are symbiotic N-fixers. Nitrogen-fixing species at SMRNA (Ceanothus spp. and Purshia tridentata Pursh.) were documented on nearly every mudflow surface (Dickson and Crocker, 1953a). However, at the Forest Falls chronosequence there was only one symbiotic N-fixing plant species (Cercocarpus ledifolius Nutt.), which was observed on the $20 \mathrm{yr}$-old surface only (Turk, 2007). Likewise, at SDEF, the Coulter pine lysimeter was not planted with any $\mathrm{N}$-fixing species.

At Forest Falls and SDEF, atmospheric deposition is likely to be an important source of $\mathrm{N}$. The $\mathrm{N}$ accumulation rate at Forest Falls $\left(0.8 \mathrm{~g} \mathrm{~m}^{-2} \mathrm{yr}^{-1}\right)$ (Table 2$)$ is within the range of dry deposition rates of $\mathrm{N}$ at Barton Flats $\left(0.5-0.9 \mathrm{~g} \mathrm{~m}^{-2} \mathrm{yr}^{-1}\right.$ ) (Bytnerowicz and Fenn, 1996), which is five miles north of Forest Falls. Likewise, the $\mathrm{N}$ accumulation rate observed at the SDEF lysimeters $\left(1.9 \mathrm{~g} \mathrm{~m}^{-2} \mathrm{yr}^{-1}\right)$ (Table 2 ) could be entirely accounted for by the high the $\mathrm{N}$ deposition rate at the site $\left(2.0-3.5 \mathrm{~g} \mathrm{~m}^{-2} \mathrm{yr}^{-1}\right.$ ) (Bytnerowicz and Fenn, 1996). The distribution of $\mathrm{N}$ between organic and mineral horizons is subject to the same influences discussed for $\mathrm{C}$ accumulation, including surface litter originating from adjacent older surfaces and increased litterfall due to ozone damage (Takemoto et al., 2001).

\section{SUMMARY AND CONCLUSIONS}

Accumulation of $\mathrm{C}$ and $\mathrm{N}$ in the soils at Forest Falls occurs mainly in the organic horizons. Carbon accumulation in the organic horizons can be described by a linear trend with a slope of $26.5 \mathrm{~g} \mathrm{~m}^{-2} \mathrm{yr}^{-1}$, which is uniform throughout the time frame of the chronosequence. Nitrogen accumulation in the organic horizons also follows a linear trend, with a slope of $0.63 \mathrm{~g} \mathrm{~m}^{-2} \mathrm{yr}^{-1}$. Most of the $\mathrm{C}$ and $\mathrm{N}$ accumulation in the organic horizons occurred in fractions that were highly decomposed or composed of woody materials.

In the mineral horizons, $\mathrm{C}$ accumulation occurred from $<1$ to $82 \mathrm{yr}$, at a rate of $13 \mathrm{~g} \mathrm{~m}^{-2} \mathrm{yr}^{-1}$ and was nearly stable from 
82 to $244 \mathrm{yr}$. The rate of $\mathrm{N}$ accumulation was best described by a linear trend with a slope of $0.17 \mathrm{~g} \mathrm{~m}^{-2} \mathrm{yr}^{-1}$ and there was no change in trend over the course of the chronosequence. These rates reflect accumulation in the upper $30 \mathrm{~cm}$ of the mineral soils only. Limiting the analysis to this depth was necessary to include the shallow debris flow deposits so that enough data was available to resolve trends, such as the change in $\mathrm{C}$ accumulation rate at $82 \mathrm{yr}$. However, another implication is that $\mathrm{C}$ and $\mathrm{N}$ stored deeper in the soil have not been included.

By the end of this 244-yr chronosequence, the C pool, including the organic horizons and the mineral soil through the $1-\mathrm{m}$ depth, was $9 \mathrm{~kg} \mathrm{~m}^{-2}$. This approaches the size expected in a mature coniferous forest. This study, therefore, suggests that there is a rapid recovery of the soil organic $\mathrm{C}$ pool following disturbance by debris flows. The $\mathrm{N}$, however, accumulates very slowly in the soils and shows no sign of stabilization within the recurrence interval between debris flows at the site.

\section{ACKNOWLEDGMENTS}

This research was supported by the Kearney Foundation for Soil Science. Doug Morton introduced us to the field area. Susan Akers, Jacob Berkowitz, Sheila Furquim, Brett Goforth, Daniel Hirmas, Katherine Kendrick, and Rodrigo Vargas were involved in the preliminary research at the site. Joshua Barraza and Shahriar N. Uddin helped with field work.

\section{REFERENCES}

Birkeland, P.W. 1999. Soils and geomorphology. 3rd ed. Oxford Univ. Press, New York.

Blake, G.R., and K.H. Hartge. 1986a. Bulk density. p. 363-376. In A. Klute (ed.) Methods of soil analysis. Part 1.2nd ed. Agron. Monogr. 9. ASA and SSSA, Madison, WI

Blake, G.R., and K.H. Hartge. 1986b. Particle density. p. 377-383. In A. Klute (ed.) Methods of soil analysis. Part 1. 2nd ed. Agron. Monogr. 9. ASA and SSSA, Madison, WI.

Boone, R.D., D.F. Grigal, P. Sollins, R.J. Ahrens, and D.E. Armstrong. 1999. Soil sampling, preparation, archiving, and quality control. p. 3-28. In G. Philip (ed.) Standard soil methods for long term ecological research. Oxford Univ. Press, New York.

Bytnerowicz, A., and M.E. Fenn. 1996. Nitrogen deposition in California forests: A review. Environ. Pollut. 92:127-146.

Dickson, B.A., and R.L. Crocker. 1953a. A chronosequence of soils and vegetation near Mt. Shasta, California. 1. Definition of the ecosystem investigated and features of the plant succession. J. Soil Sci. 4:123-141.

Dickson, B.A., and R.L. Crocker. 1953b. A chronosequence of soils and vegetation near Mt. Shasta, California. 2. The development of the forest floors and the carbon and nitrogen profiles of the soil. J. Soil Sci. 4:143-153.

Dickson, B.A., and R.L. Crocker. 1954. A chronosequence of soils and vegetation near Mt. Shasta, California. 3. Some properties of the mineral soils. J. Soil Sci. 5:173-191.

Godt, J.W. 2001. Landslide incidence and susceptibility in the conterminous United States. Available at http://www.nationalatlas.gov/mld/lsoverp. html (Verified 18 June 2009). USGS, Reston, VA.

Harden, J.W. 1987. Soil development in granitic alluvium near Merced, California. U.S. Geol. Surv. Bull. 1590-A. U.S. Gov. Print. Office, Washington, DC.

Harden, J.W., A.M. Sarna-Wojcicki, and G.R. Dembroff. 1987. Soils developed on coastal and fluvial terraces near Ventura, California: U.S. Geol. Surv. Bull. 1590-B. U.S. Gov. Print. Office, Washington, DC.

Hirmas, D.R., and S.A.C. Furquim. 2006. Simple modification of the clod method for determining bulk density of very gravelly soils. Commun. Soil Sci. Plant Anal. 37:899-906.

Kern, J.S. 1994. Spatial patterns of soil organic-carbon in the contiguous United-

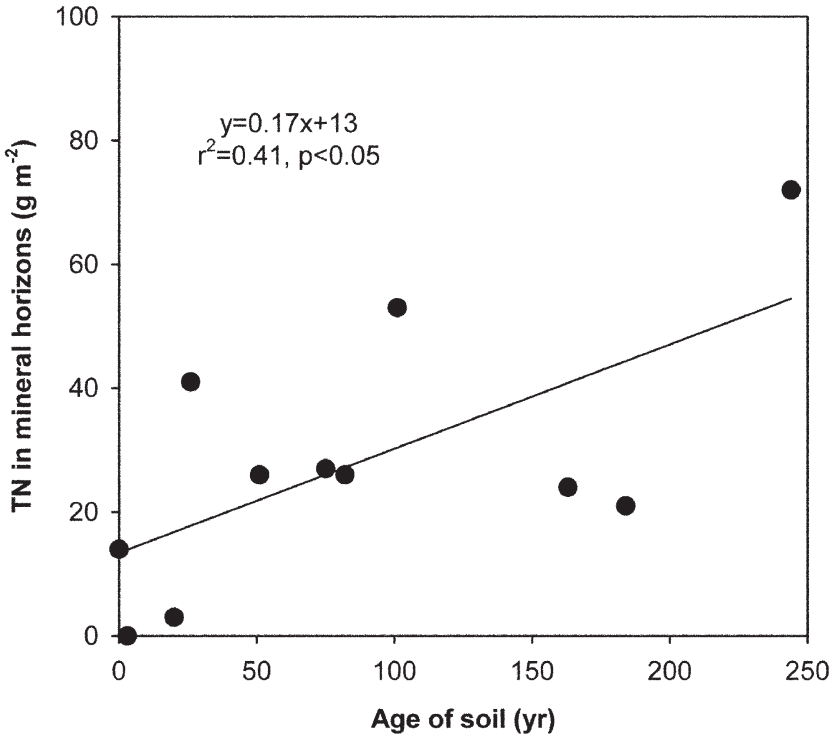

Fig. 5. Total nitrogen (TN) in the mineral soil horizons through a depth of $30 \mathrm{~cm}$.

States. Soil Sci. Soc. Am. J. 58:439-455.

Lilienfein, J., R.G. Qualls, S.M. Uselman, and S.D. Bridgham. 2003. Soil formation and organic matter accretion in a young andesitic chronosequence at Mt. Shasta, California. Geoderma 116:249-264.

Morton, D.M., R.M. Alvarez, K.R. Ruppert, and B. Goforth. 2008. Contrasting rainfall generated debris flows from adjacent watersheds at Forest Falls, southern California, USA. Geomorphology 96:322-338.

Post, W.M., W.R. Emanuel, P.J. Zinke, and A.G. Stangenberger. 1982. Soil carbon pools and world life zones. Nature 298:156-159.

Quideau, S.A., R.C. Graham, O.A. Chadwick, and H.B. Wood. 1998. Organic carbon sequestration under chaparral and pine after four decades of soil development. Geoderma 83:227-242.

San Bernardino Flood Control District. 2008. San Bernardino County Flood Warning Systme. Available at: http://www.sbcounty.gov/trnsprtn/pwg/ alert/reports.html. (verified 1 June 2009)

Schimel, D., I.G. Enting, M. Heimann, T.M.L. Wigley, D. Raynaud, D. Alves, and U. Siegenthaler. 1995. CO2 and the carbon cycle. p. 35-71. In J.H. Houghton et al (ed.) Climate change 1994. Cambridge Univ. Press, Cambridge.

Schlesinger, W.H. 1990. Evidence from chronosequence studies for a low carbonstorage potential of Soils. Nature 348:232-234.

Swift, M.J., O.W. Heal, and J.M. Anderson. 1979. Decomposition in terrestrial ecosystems University of California Press, Berkeley.

Takemoto, B.K., A. Bytnerowicz, and M.E. Fenn. 2001. Current and future effects of ozone and atmospheric nitrogen deposition on California's mixed conifer forests. For. Ecol. Manage. 144:159-173.

Turk, J.K. 2007. Soil development in a forested debris flow chronosequence in southern California. M.S. thesis. Univ. of California, Riverside.

Turk, J.K., B.R. Goforth, R.C. Graham, and K.J. Kendrick. 2008. Soil morphology of a debris flow chronosequence in a coniferous forest, southern California. Geoderma 146:157-165.

Ulery, A.L., R.C. Graham, O.A. Chadwick, and H.B. Wood. 1995. Decade-scale changes of soil carbon, nitrogen and exchangeable cations under chaparral and pine. Geoderma 65:121-134.

USDA-Forest Service. 2002. Forest cover types. Available at http://nationalatlas. gov/mld/foresti.html (Verified 1 June 2009). National Atlas of the United States, Reston, VA.

Whittaker, R.H., and G.E. Likens. 1975. The biosphere and man. p. 305-328. In H. Lieth and R.H. Whittaker (ed.) Primary productivity of the biosphere. Ecological studies 14. Springer-Verlag, New York.

Williams, D.E. 1948. A rapid manometric method for the determination of carbonate in soils. Soil Sci. Soc. Am. Proc. 13:127-129. 